\title{
Hombres armados en lucha por poder. Córdoba de la pos independencia
}

Valentina Ayrolo

Valentina Ayrolo es Investigadora del CONICET y Profesora de la Universidad Nacional de Mar del Plata.

Funes 3350-7600, Mar del Plata

e-mail: vayrolo@mdp.edu.ar

\section{Resumen}

El problema de la instauración de algún tipo de organización estable en las provincias que habían quedado desarticuladas por la revolución y la guerra fue, evidentemente, el mayor desafío del período que abre el fin de la guerra independentista hacia los años 1820. En este marco se analizan una serie de movimientos armados ocurridos en el escenario de la provincia de Córdoba entre 1815 y 1840, considerando principalmente tres cuestiones: composición posible de los grupos, los hombres que encabezaron los movimientos y los objetivos presumibles de la movilización.
Una primera versión de este trabajo fue presentada en las $X$ Jornadas Interescuales-Departamentos de Historia, Rosario, de septiembre 2005; y una versión revisada y aumentada en las II Jornadas de Trabajo y Discusión, Problemas y Debates del Siglo XIX. Mar del Plata, mayo de 2007. La autora agradece los comentarios y sugerencias recibidas por parte Eduardo Míguez, Fabián Herrero, Sara Mata y Beatriz Bragoni. Todos ellos le fueron de gran ayuda para pensar el problema tratado en este texto.

\section{Summary}

The installation of some sort of stable organization in the provinces that had been destabilized for the revolution and war was, by far, the most important challenge of the 1820 at the end of the independence war. Taking this context into account, this paper analyses a number of armed movements that took place in the province of Córdoba between 1815 and 1840, considering the following three questions mainly: the composition of the groups, the leaders of the movements and the purposes of those mobilizations. 